\title{
Exogenous and Endogenous Impacts into Teachers' Work Performance Sphere
}

\author{
Nasrun $^{1}$ \\ ${ }^{1}$ Faculty of Education Science, Medan State University, Indonesia \\ Correspondence: Nasrun, Faculty of Education Science, Medan State of University, Medan Estate, Indonesia. Tel: \\ 1-613-947-3592. E-mail:Nasrunstion@gmail.com
}

Received: September 10, $2015 \quad$ Accepted: October 11, 2015 Online Published: January 25, 2016
$\begin{aligned} & \text { doi:10.5539/ies.v9n2p99 } \\ & \text { URL: http://dx.doi.org/10.5539/ies.v9n2p99 }\end{aligned}$

URL: http://dx.doi.org/10.5539/ies.v9n2p99

\begin{abstract}
By this synopsis research which conveyed of findings to unfold mutual effect between teachers' performance and incentive scheme and teachers' personal competency, and principal leadership, and work motivation, by means of explanatory research in which ex facto method was ad hock model chosen because of classified as non-experiment. The grounds populations of research target were upon teachers of Public Senior High School around Medan city which the total about 1446 teachers, 241 teachers set out as sample apart. Though Ex post facto as a means to examine proposed hypothesis it was found significant influence between free variable teacher's personal competence toward work motivation and teacher's work performance as bound variable. Carried out with statistical descriptive analysis and inferential analysis. Alluded to inferential analysis by technically path coefficient analysis whereby direct contribution of: 1) incentive scheme toward work motivation was $41 \%$, 2) teachers personal competency toward work motivation was $17 \%$. 3) Principal leadership toward work motivation was $25 \%$. 4) Incentive scheme toward teachers' work performance 17\%. 5) Principal leadership toward teachers' work performance was $16 \%$. 6) Work motivation toward teachers' work performance was $39 \%$.
\end{abstract}

Keywords: incentive scheme, principal leadership, teachers work performance, teachers personal competency, work motivation

\section{Introduction}

The main task of teacher is to educate, teach, guide, direct, train, assess, and evaluate students in a very early age through formal education, of elementary and middle level. Official duty implementation exercising skills, adroitness which met the qualification's standard or certain norms attained through professional education. A teacher should have been obliged to demonstrate a high performance, by that way could motivate and facilitate students in order to exert the best potential. In extent of pursuing its educational set off goal, an educator required to demonstrate good work which begun with setting plan, devise strategy, pick material and learning method, and exact assessment.

Mangkunegara (2001, p. 67) paraphrased of job performance/actual performance interpreted to become job attainment or accomplishment. Job accomplishment is dictated by knowledge, prowess, and competency on the job. Job accomplishment associated with some influenced factors. Gibson, Ivancevich, and Donnely (2009, p. 234) theoretically expressed of three variable group which immediately impacted to job performance and behavior includes: (1) Individual variable embraced ability and skill, physical or mental, background, experience and demography, age, and gender, offspring and so on. (2) Organizational variable, such as resources, management, incentive, structure and work design, (3) Psychological variable such as perception, attitude, personification, learning, job satisfaction, and motivation.

A research which conducted by Chamberlin (2002, p. 34) discovered that incentive scheme performance-based had a long history in realms of education yield, especially in United States. In the last decade, some countries had adopted a strategy in incentive scheme performance-based to modify paying salary by traditional system. A factor to distinguish incentive scheme performance-based is that of wages based on after work evaluation. Saragih (2008, p. ii) assumed that simultaneously incentive and education and training has an effect on teacher work performance, in other hand Obi $(2002$, p. 29) suggested that to become a headmaster or principal be as leader too, the principal supposedly paying special attention on teachers' enhancement program implicitly has an effect on performance. An observation conducted by Enueme and Eqwunyenga (2008, p. 13) extrapolated that 
principal who explained instruction clearly has coherently impacted on teachers' performance

Teachers are the pivotal aspects who mould students to gain sciences, skills, and rite values and social. Therefore a teacher can represent social agent that must have been kept an eye on teaching presentation. A teacher is the one who unswerving teaching learning process in the class meeting. Teachers' teaching seriousness relied upon work motivation and professional competence. A teacher is an educational facilitator and teaching leadership in the class meeting. A teacher is a pattern before the students should have manifested role model throughout lives. That why a teacher should always sways to keep up good deed, self-esteem before students. Buhler (2004, p. 191) expressed that motivation basically is a stimulable process which governs how much efforts did to do the job. Motivation and inducement to stay working is one of the aspects which ascertain to job accomplishment. The meaning of motivation is closely related to conjure up tendentiousness to do something in the faculty of getting goal. Gagne (1999, p. 45) inferred that a work motivation brings about positive sway on employee performance, attitude, creativity, and professional trust worthy. Mulyasa (2006, p. 75) prompted that motivation makes an impression on teachers' performance. This opinion alluded to Sardiman (2004, p. 34) said motivation as an aspect to sway teachers' performance in doing learning teaching process. Hamalik (2002, p. 89) stated designed curriculum, will not work, if teachers are not seriously and owned high motivation.

\section{Theoretical Study}

\subsection{Performance}

Miner (1992, p. 612) proposed performance is an expected behavioral congruent by a certain company. Griffin (1997, p. 464) wrote that performance is a demonstrated behavioral totality in a work. Sikula in Hasibuan (2001, p. 87) conceded evaluative performance is a systematic evaluation on job performed as a means of making job better. Dale Yoder in Hasibuan (2007, p. 89) defined evaluative performance became a formal procedure to evaluate employees and contributed to themselves. Siswanto (2003, p. 231) evaluative performance is a managerial or supervisor proceeding. Evaluator, to evaluate human resources performance by comparing of performance over performance with its description in a certain terms of period.

\subsection{Incentive Scheme}

Incentive by Capacity Development Resources quoted that incentive is an external action which designed, substantiated that which can effect motivation and individual behavior, group or organization. The phases of paying incentive, as salary, secondary allowance and non-financial profit, admittance or sanction work for making better job performance. Paying incentive technically granting compensation to employee of what they did. Generally paying incentive designed for rewarding on good job accomplishment. Buchan et.al (2000, p. 34) assumed three effective incentive scheme strategy, they are: First, incentive scheme is congruent with whole company strategy. Secondly, congruent with organizational objective and work type. Thirdly, having positive forward movement.

Moorehead and Griffin (1992, p. 98) defined incentive as a scheme or reward on individual or group who demonstrated good work granted exclusively out of regular salary. Dessler (1998, p. 141) wrote that incentive scheme is spontaneous rendering bonus on satisfied job accomplishment. Incentive scheme has another form application such as: first, in a form of health insurance, secondly in a form of retirement fund, thirdly in a form of carrier appraisal or promotion, fourthly Christmas (big holiday) allowance. Heneman (2007, p. 12) defined incentive scheme with paying cash of bonus on good job accomplishment, commented as well about incentive scheme with four phases: First, assessment on teachers' job performance. Secondly, teachers' superior design on rewarding incentive. Thirdly, rendition to whom its eligible to get. Fourthly, evaluation of which rendering incentive has taken an effect on teachers' performance get better.

\subsection{Personal Competency of Teacher}

Personal competency of teachers is a part of consideration to see the appropriateness of teachers' qualification. Attitude and misbehavior must have left behind to escape of misinterpretation. Teachers are role model before their students. The teacher should stand upright and keep good will and honorable, and implement noteworthiness, godliness, integrity by words and actions.

In the teacher's bylaw prescribed personal competency is a good intelligence, noble, sane, honorable and role model before students. Surya (2004, p. 4) in National Educational Department underlined personal competency is a teachers' intelligence mostly required becoming respected teacher. Personal competence includes personal intelligence which is properly to self-awareness, self-acceptance, self-guidance and self-actualization. Gumelar and Dahyat (2004, p. 5) in National Educational Department referred the opinion of Asian Institute for Teacher Education presented personal competency included: (1) consciousness about culture of society or creed. (2) 
awareness about customs and tradition, (3) knowledgeable about democracy, (4) pedantry of esthetic, (5) appreciative and social concern, (6) has intellectuality and job, (7) steadfastness on ethics and moral values. Johnson in Anwar (2004:63) asserted teachers' competence covered: (1) positive attitude appearance as a whole as teachers' obligation across educational condition and its components, (2) perception, contemplation and exhibit values that which a teacher is required of, (3) personality, values, attitude that should be played as a right pattern before the students. Arikunto in National Educational Department (2004, p. 5) said that personal competency to suppose teachers have a tremendous personality to imbue students and being emulated.

\subsection{Principal's Leadership}

Hill and Caroll (1995, p. 65) suggested that leadership could be defined as a prowess to move people forward collaboratively in doing any activities, straightforward in unison objective. Organizational structure is a frame or arrangement unit or unity or work team or job description or main job duty in an organization for a specified goal. Killian (2007, p. 4) in his book about leadership unfolded a lot of pre-studies in the matters of leadership who endeavor identifying the characteristics of effective leader. In terms of a research of characteristics of effective leader mainly is to have personal characteristic specifically referred to aptitude and other personal aspect. The first, personal characteristic is a cognitive domain consisted of tendency to take over decision making, self-confident, extrovert. The second, consciousness of craving or good career, invigorated up, initiative. The third, is a social behavior inclination consisted of affection, good listening and less self-oriented. The last is internal locus of control consisted of optimism, steadfastness, consistency.

School is an institution where the place to get and to give lessons. Hence principal could be simply defined as a teacher obliged to lead a school where learning teaching process performed, or where the place to get a mutual interaction between teachers and students. Daryanto (2005, p. 80) defined a principal is personnel who is in charge of a whole school's activities. Principal has an authorization and accountable to run overall school's activities, surrounding school or even to foster good external relationship with societies, students' parents, local government. Daum (2003, p. 23) explained of some principles in connection with leadership definition, first a leader should have enabled to create managerial performance climate which measured by competed accomplishment not just focused to only internal budgeting. Second, a leader should be able aspire motivation by challenge and credibility. The third and fourth delegate downward responsibilities to operational manager in manner of adeptness to make decision itself, and let them act independently (free access to direct human resources). The fifth, the leader to be aware of organization is customers-oriented. The sixth, a leader should organize information system and open strategy and transparency in order of all employees understand organizational objective.

\subsection{Work Motivation}

Motivation argues of how to direct subordinates' potency in order to work productively to achieve the set objective. By Hasibuan (2001, p. 95) the root word of motivation is motive, which means it has a stimulation, craving, and psychomotor of work. Motivation is psychometric gift which creates work ethos excitement to work cooperatively, effectively and integrated with overall endeavors to get satisfaction. Robbins (2001, p. 166) motivation is readiness to explore high exertion for organizational objective which conditioned by enforcement for individual sustenance. Amirullah et al. (2002, p. 146) implied work motivation is a condition which has an effect on rekindling, directing and keeping behavior in connection with work environment. By Winardi (2002, p. 6) work motivation is an inner potential enforcement, which can be nourished by throughout enforcement that in its core about monetary compensation and non-monetary compensation which can have an effect on positive work accomplishment or negatively, it depends on situation and condition which dealt with thereof. Colquitt, LePine, and Wesson (2009, p. 178) described motivation is latent great inner strength that which energetically coordinating within and without of workers themselves, which moved them to work to set the path, intensity, and persistency.

In light of theoretical study and thinking frame, designed variable theoretical model observation displayed on that figure below: 


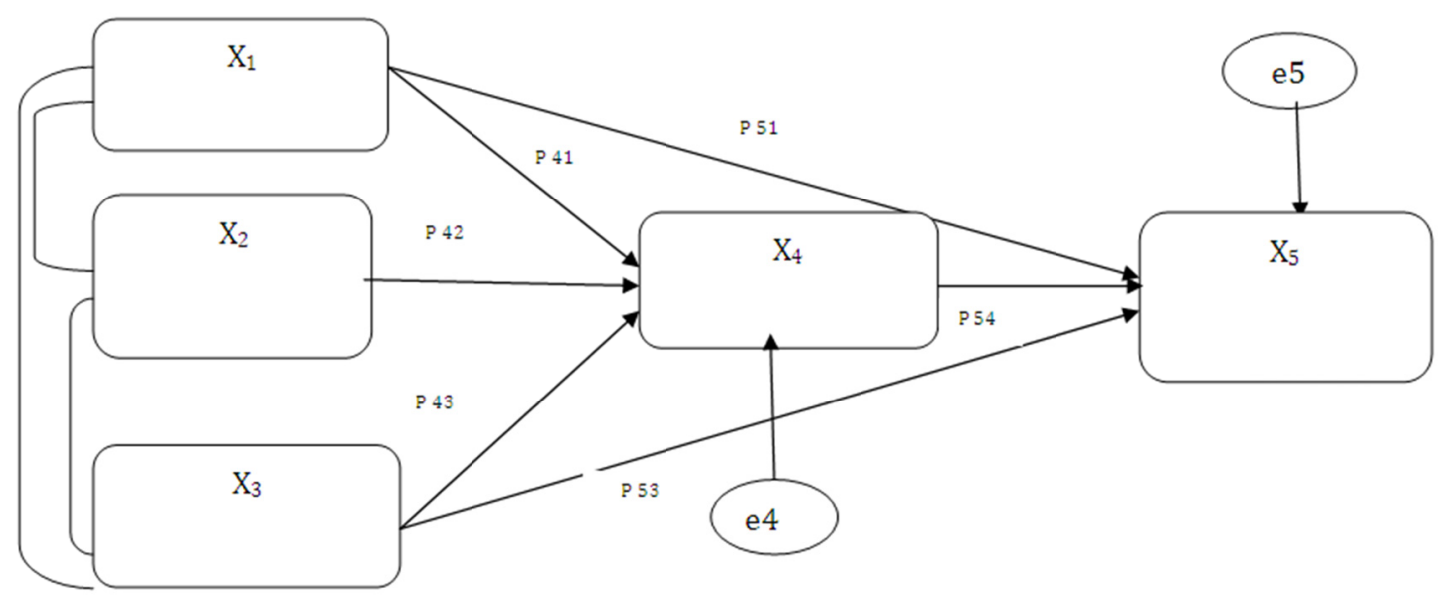

Figure 1. Paradigmatic Research

\section{Explanation:}

$\mathrm{X}_{1} \quad$ : Incentive Scheme

$\mathrm{X}_{2}$ : Teachers' Personal Competence

$\mathrm{X}_{3}$ : Principal's leadership

$\mathrm{X}_{4}$ : Work Motivation

$\mathrm{X}_{5} \quad$ : Teachers' Performance

\section{Methodological Method}

Methodological research worked out with ex post facto model because of classified as non-experiment, comprised 5 variables with path analysis. Population applied on Public Senior High School teachers around Medan city. Based on data analysis selected 1446 teachers, who are sampled about $16.67 \%$ or 240.50 or rounded to 241 people taken out as samples.

Instruments that employ questionnaires sheet into observation which validity and reliability pretested. Instrumental validity counted by riding on correlative moment product, at the mean time examined reliability employed Inter Rater Reliability and Cronbach Alpha.

In this observation, that the instrumental experiment is imposed upon 40 teachers who represent all Senior High School Public School Teachers in Medan City.

Instrumental Validity Test assigned correlative formula Karl Pearsons.

Whereas: $\quad r_{x y}=$ Correlative Coefficient Item

$\mathrm{Z} \mathrm{x}$ = Standard Score of Variable $\mathrm{X}$

$\mathrm{Z} y=$ Standard Score of Variable $\mathrm{Y}$

$\mathrm{N} \quad$ Number of Respondents

Next to examine correlation using the formula:

$$
t=\frac{r_{x y} \sqrt{n-2}}{{\sqrt{1-r^{2}}}_{x y}}
$$

Whereas: $\mathrm{t}=\mathrm{t}_{\text {count }}$

$$
\begin{aligned}
& r_{x y}=\text { Correlative Coefficient Item } \\
& \mathrm{n}=\text { Number of Respondents }
\end{aligned}
$$

Afterward the value of $\mathrm{t}_{\text {count }}$ consulted with the value of $\mathrm{t}_{\text {table }}$ on $\alpha=0.005$, and $\mathrm{dk}=\mathrm{n}-2$. If $\mathrm{t}_{\text {count }}$ is greater than $t_{\text {table, }}$, then the item's representation declared valid. 
Based on the results of experiment on instrument, the validity of item on each researched instrument expounded as follows:

1) Instrumental Item Validity of Teachers' Performance.

The results of instrumental item validity of teacher's performance inferred that all instrumental items met the validity terms.

2) Instrumental Item Validity of Incentive Scheme

The result of instrumental item validity of incentive scheme exhibited the numbers instrumental items which met the requirement were 34 items of 40 total items of tested instrument. Invalid instrumental items were 6 items.

3) Instrumental Item Validity of Teachers' Personal Competency

Under this point found 37 items of instrument met the terms of validity out of 40 total items. The items which are not valid were 3 items.

4) Instrumental Item Validity of Principals' Leadership.

This observation earned 35 items of 40 total items of instrument which met the requirement. 5 items of instrument are not valid.

5) Validity of Instrument on Work Motivation.

There are 34 out of 40 items of variable instrument which met the terms. That 6 items are not valid. Subsequent present recapitulation of total items tested, the items which dropped and valid and lowest and highest score:

Table 1. Test result of items validity on each variable

\begin{tabular}{|c|c|c|c|c|c|}
\hline Variable & $\begin{array}{l}\text { Total Items } \\
\text { Tested }\end{array}$ & Items Not Valid & $\begin{array}{l}\text { Total Valid } \\
\text { Items }\end{array}$ & $\begin{array}{l}\text { Min } \\
\text { Score }\end{array}$ & Max Score \\
\hline Teachers' Performance & 15 & - & 15 & 15 & 75 \\
\hline Incentive Scheme & 40 & 6 & 34 & 34 & 170 \\
\hline $\begin{array}{l}\text { Teachers' } \\
\text { Competency }\end{array}$ & 40 & 3 & 37 & 37 & 185 \\
\hline Principals' Leadership & 40 & 5 & 35 & 35 & 175 \\
\hline Work Motivation & 40 & 6 & 34 & 34 & 170 \\
\hline
\end{tabular}

b) Reliability Test

To Instrument of Incentive Scheme, Teachers' Personal Competent, Teachers' Leadership, and Work Motivation riding Alpha Cronbach with the formula as follows:

$$
a=\frac{n}{n-1}\left[1-\frac{\sum S_{i}^{2}}{S_{i}^{2}}\right]
$$

Whereas $\alpha=$ Coefficient Reliability

$\mathrm{n}=$ Total Valid Items

$\mathrm{Sx}^{2}=$ Total Score Variance

$\mathrm{Si}^{2}=$ Items Score Variance

To examination of inter rater reliability on teachers' work performance worked by trying instrument to assess a teaching teachers by five raters which were trained by researcher (Principals/Vice Principals). And there after prepared different variance analysis between observer (rater) and statistical ANOVA with Hyot method. Meanwhile to variable instrument of incentive scheme, teacher's personal competency, principals' leadership and work motivation in order to examine correlation employing formula which is in accord with test validity. The next that value $t_{\text {count }}$ consulted with value $t_{\text {table }}$ on $\alpha=0.05$, and $d k=n-2$. If $t_{\text {count }}$ is greater than $t_{\text {table, }}$, then the items statement declared reliable.

Instrumental researched criteria stated reliable if alpha coefficient worth is greater than 0.60 . The result on tested 
instrumental reliability each observing variable could be defined as follows:

\section{1) Instrumental Item Reliability of Teachers' Performance}

The Analysis of instrumental item reliability on teachers' performance variabel, taken after count and sum up that the variance between observers pointed out different observation from 5 observer (rater) is not different significantly. Because $\mathrm{F}$ count $\leq \mathrm{F}$ table $(2.5 \leq 4.70)$, then there is no difference significantly. It means there is no different result between rater and instrument used has a readability phase which is relatively alike between rater.

2) Instrumental Reliability on Incentive Scheme

The Analysis of variable instrumental reliability on incentive scheme which totally 34 items based on out-put SPSS. The counting result 0.88 and after consulted on interval scale of correlative level force, then instrumental correlative coefficient variable on incentive scheme classified in a high category. Therefore the instrument to incentive scheme has high reliability. Recapitulation tested result of incentive scheme instrument explicitly on Exhibition 2.

3) Reliability of Teachers' Competency

The Analysis instrumental item reliability variable teachers' personal competency totaled 37 items based on out-put SPSS. The end calculation of reliability of instrument at variable teachers' personal competency of 0.92 and after consulted on interval scale of the phase of correlative force, then correlative coefficient instrument variable of teachers' personal competency has high reliability. Recapitulation conveyed in Exhibition 2.

4) Reliability of Principal's Leadership

The Analysis totaled 35 items based on out-put SPSS. The end of calculation of 0.94 and after consulted on interval scale of correlative force level, then instrumental correlative coefficient variable of principals' leadership classified high category, therefore has high reliability. Recapitulation exerted in Exhibition 2.

5) Reliability of Work Motivation

The Analysis instrumental item reliability variable of work motivation totaled 34 items based on out-put SPSS. The calculation result of 0.87 and after consulted on interval scale of correlative force level, then instrumental correlative coefficient variable of work motivation classified high category, therefore has high reliability. Recapitulation displayed on Exhibition 2.

Based on instrumental reliability test result which prepared on all examined construct has a value $\alpha>0.60$. The more detailed instrumental reliability test result conveyed on Table 2 .

Table 2. Detailed instrumental reliability test result variable observation

\begin{tabular}{lccl}
\hline \multicolumn{1}{c}{ Variable } & Total Item & $\alpha$ & Explanation \\
\hline Teachers' Performance & 15 & t.tab $\leq$ t.count & Reliable \\
Incentive Scheme & 34 & 0.88 & Reliable \\
Teachers' Personal Competency & 37 & 0.92 & Reliable\# \\
Principals' Leadership & 35 & 0.94 & Reliable\# \\
Work Motivation & 34 & 0.87 & Reliable\# \\
\hline
\end{tabular}

Requirements test analysis designed to meet Pedhazur's thoughts that: 1) intra- correlation variable model is linear (linearity test), 2) residual variable not correlate with variable to be examined and nor with autocorrelation test. 3) intra-correlation variable within model is a causal relationship/recursive (multi-colienarity). 4) variable must in interval scale and 5) measured variable must free of error (measureable). The next to examine causal model employed path analysis with the assistance of AMOS 18 . 


\section{Results of Research and Discussion}

\subsection{Result of Research}

Description data of five variables, exhibited on the Table 3, down below:

Table 3. Description summary of data research

\begin{tabular}{lccccc}
\hline \multirow{2}{*}{ Analysis } & \multicolumn{5}{c}{ Variable } \\
\cline { 2 - 5 } & $\mathrm{X}_{1}$ & $\mathrm{X}_{2}$ & $\mathrm{X}_{3}$ & $\mathrm{X}_{4}$ & $\mathrm{X}_{5}$ \\
\hline Sum of data (N) & 241 & 241 & 241 & 241 & 241 \\
Minimum Score & 72 & 81 & 63 & 82 & 36 \\
Maximum Score & 168 & 180 & 173 & 170 & 64 \\
Range & 96 & 99 & 110 & 88 & 28 \\
Sum of Interval Class & 9 & 9 & 9 & 9 & 8 \\
Interval & 12 & 13 & 14 & 11 & 5 \\
Average & 124.15 & 141.78 & 128.56 & 133.46 & 52.95 \\
Standard Deviation & 18.84 & 22.41 & 24.98 & 19.72 & 5.52 \\
Mean & 122.59 & 145.02 & 132.09 & 135.73 & 52.89 \\
Modus & 112.72 & 151.55 & 131.46 & 138.52 & 52.59 \\
Minimum Ideal Score & 34 & 37 & 35 & 34 & 15 \\
Maximum ideal Score & 170 & 185 & 175 & 170 & 75 \\
Ideal Average & 102 & 111 & 105 & 102 & 45 \\
Ideal Standard deviation & 22.67 & 24.67 & 23.33 & 22.67 & 10 \\
\hline
\end{tabular}

\subsection{The Test of Data Research Quality}

The test of data research quality ridden on by normality test, linearity test, autocorrelation test, and multi-co-linearity, with results of all variables can meet requirements analysis.

The end of calculation with AMOS 18 program exhibited the value of path coefficient each of variables exogenous against endogenous as exhibited on the Table 4 down below:

a. The end calculation of path coefficient sub-structure 1

Table 4. The summary of the calculation of path coefficient sub-structure I

\begin{tabular}{lccccc}
\hline \multirow{2}{*}{ Variable } & \multirow{2}{*}{ Correlation } & \multicolumn{3}{c}{ Impact on Variable X4 } & \multirow{2}{*}{ Disguised Impact } \\
\cline { 3 - 5 } & & Direct Impact & Indirect Impact & Total & \\
\hline $\mathrm{X}_{1}$ & 0.578 & 0.411 & 0 & 0.411 & 0.167 \\
$\mathrm{X}_{2}$ & 0.405 & 0.169 & 0 & 0.169 & 0.236 \\
$\mathrm{X}_{3}$ & 0.484 & 0.249 & 0 & 0.249 & 0.235 \\
\hline
\end{tabular}

Tracing on calculation result of path coefficient sub-structure 1 , indicated that incentive scheme $\left(\mathrm{X}_{1}\right)$ immediately hit on teachers' motivation $\left(\mathrm{X}_{4}\right)$ as of 0.411 with correlation 0.578 which meant has moderate or adequate correlation. Direct Impact of teachers' personal competency $\left(\mathrm{X}_{2}\right)$ over work motivation $\left(\mathrm{X}_{4}\right)$ as of 0.169 and correlation of 0.405 which meant it has connection moderately or adequately. Meanwhile enormous immediate impact of principal leadership $\left(\mathrm{X}_{3}\right)$ over teacher's work motivation $\left(\mathrm{X}_{4}\right)$ as of 0.249 and correlation of 0.484 which referred moderate or adequate connectivity. So by the end of calculation of path coefficient sub-structure 1 , hence path equation on sub-structure 1 is $\mathrm{X}_{4}=0.411 \mathrm{X}_{1}+0.169 \mathrm{X}_{2}+0.249 \mathrm{X}_{3}$, so path diagram of sub-structure 1 as follows: 


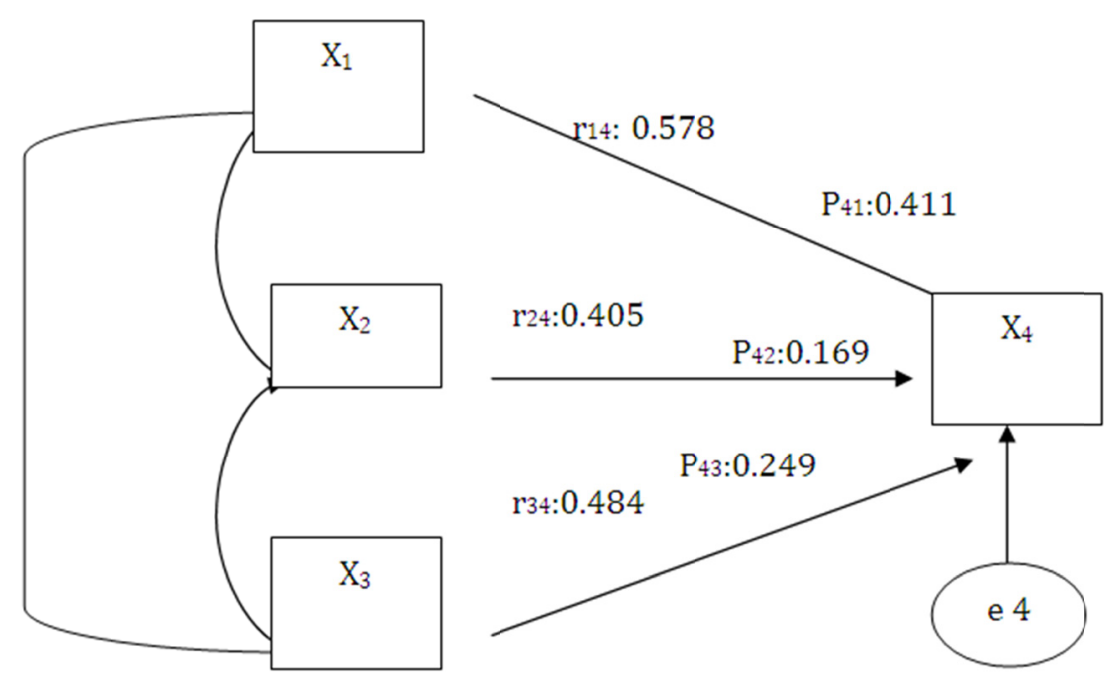

Figure 2. Path Diagram Analysis Sub-Structure 1

b. End Calculation Path Coefficient Sub-Structure 2

Table 5. Summary of end calculation path coefficient sub-structure 2

\begin{tabular}{llcccc}
\hline \multirow{2}{*}{ Variable } & \multirow{2}{*}{ Correlation } & \multicolumn{3}{c}{ Impact On Variable X5 } & \multirow{2}{*}{ Disguised Impact } \\
\cline { 3 - 5 } & & Direct Impact & Indirect Impact & Total & \\
\hline $\mathrm{X}_{1}$ & 0.635 & 0.350 & 0.172 & 0.522 & 0.113 \\
$\mathrm{X}_{3}$ & 0.488 & 0.156 & 0.110 & 0.266 & 0.222 \\
$\mathrm{X}_{4}$ & 0.656 & 0.378 & 0 & 0.378 & 0.278 \\
\hline
\end{tabular}

Derived summary on the end calculation path coefficient sub-structure 2 which figured on the Table 5 above described that incentive scheme $\left(\mathrm{X}_{1}\right)$ has a direct impact on teachers performance $\left(\mathrm{X}_{5}\right)$ as of 0.350 with correlation 0.635 which meant it has high or strong correlation. Direct impact on principal leadership $\left(\mathrm{X}_{3}\right)$ over teachers' performance $\left(\mathrm{X}_{5}\right)$ as of 0.156 and correlation of 0.488 which meant moderate or adequate correlation. Meanwhile direct impact work motivation $\left(\mathrm{X}_{4}\right)$ over teachers' performance $\left(\mathrm{X}_{5}\right)$ as of 0.378 with correlation of 0.656 which meant has its high or strong correlation. The end calculation of path coefficient also referred that existing indirect impact of incentive scheme $\left(\mathrm{X}_{1}\right)$ over teachers' performance $\left(\mathrm{X}_{5}\right)$ through work motivation $\left(\mathrm{X}_{4}\right)$ came up with 0.155 . Thus indirect impact of principal leadership $\left(\mathrm{X}_{3}\right)$ over teachers' performance $\left(\mathrm{X}_{5}\right)$ through work motivation $\left(\mathrm{X}_{4}\right)$ obtained of 0.094 . Extraction out of this findings that: (1) the growing teachers' performance up began with augmented incentive scheme which entails turning teachers' work motivation up, (2) the bringing up teachers' performance begun with the turning principal leadership up which will be followed by moving teachers' work motivation up. On the end calculation path coefficient sub-structure 2, therefore path equation on sub-structure 2 is $\mathrm{X}_{5}=0.350 \mathrm{X}_{1}+0.156 \mathrm{X}_{3}+0.378 \mathrm{X}_{4}$, otherwise diagram analysis of sub-structure 2 as figured below: 


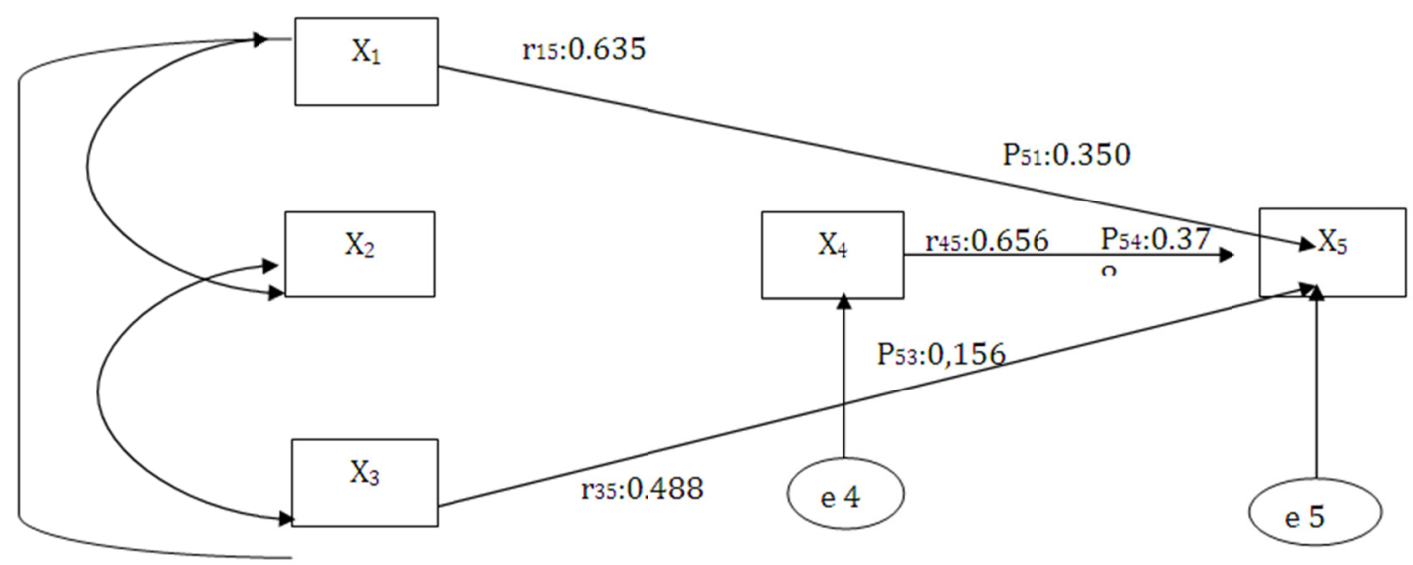

Figure 3. Diagram analysis path sub-structure 2

c. End Calculation of Path Coefficient Theoretic Model

Table 6. The summary of end calculation coefficient theoretic model

\begin{tabular}{llcccc}
\hline \multirow{2}{*}{ Variable } & \multirow{2}{*}{ Correlation } & \multicolumn{3}{c}{ Impact on Variable $\mathrm{X}_{4}$} & Disguised \\
\cline { 3 - 5 } & & Direct Impact & Indirect Impact & Total & Impact \\
\hline $\mathrm{X}_{1}$ & 0.578 & 0.411 & 0 & 0.411 & 0.167 \\
$\mathrm{X}_{2}$ & 0.405 & 0.169 & 0 & 0.169 & 0.236 \\
$\mathrm{X}_{3}$ & 0.484 & 0.249 & 0 & 0.249 & 0.235 \\
\multicolumn{5}{c}{ Impact On Variable $\mathrm{X}_{5}$} \\
$\mathrm{X}_{1}$ & 0.635 & 0.350 & 0,155 & 0.505 & 0.130 \\
$\mathrm{X}_{3}$ & 0.488 & 0.156 & 0,094 & 0.250 & 0.238 \\
$\mathrm{X}_{4}$ & 0.656 & 0.378 & 0 & 0.378 & 0.278 \\
\hline
\end{tabular}

On the table 6 above described the greatest path coefficient number is hit by incentive scheme $\left(\mathrm{X}_{1}\right)$ over variable of teachers motivation $\left(\mathrm{X}_{4}\right)$ as of 0.411 , meanwhile the least number of coefficient is a sequel of principal leadership $\left(\mathrm{X}_{3}\right)$ over teachers' performance $\left(\mathrm{X}_{5}\right)$ as of 0.156 . On the end calculation path coefficient theoretic model, so path equation is $\mathrm{X}_{4}=0.411 \mathrm{X}_{1}+0.169 \mathrm{X}_{2}+0.249 \mathrm{X}_{3}$ and $\mathrm{X}_{5}=0.350+0.156 \mathrm{X}_{3}+0.378 \mathrm{X}_{4}$, so diagram path analysis of theoretic model as completely figured below: 


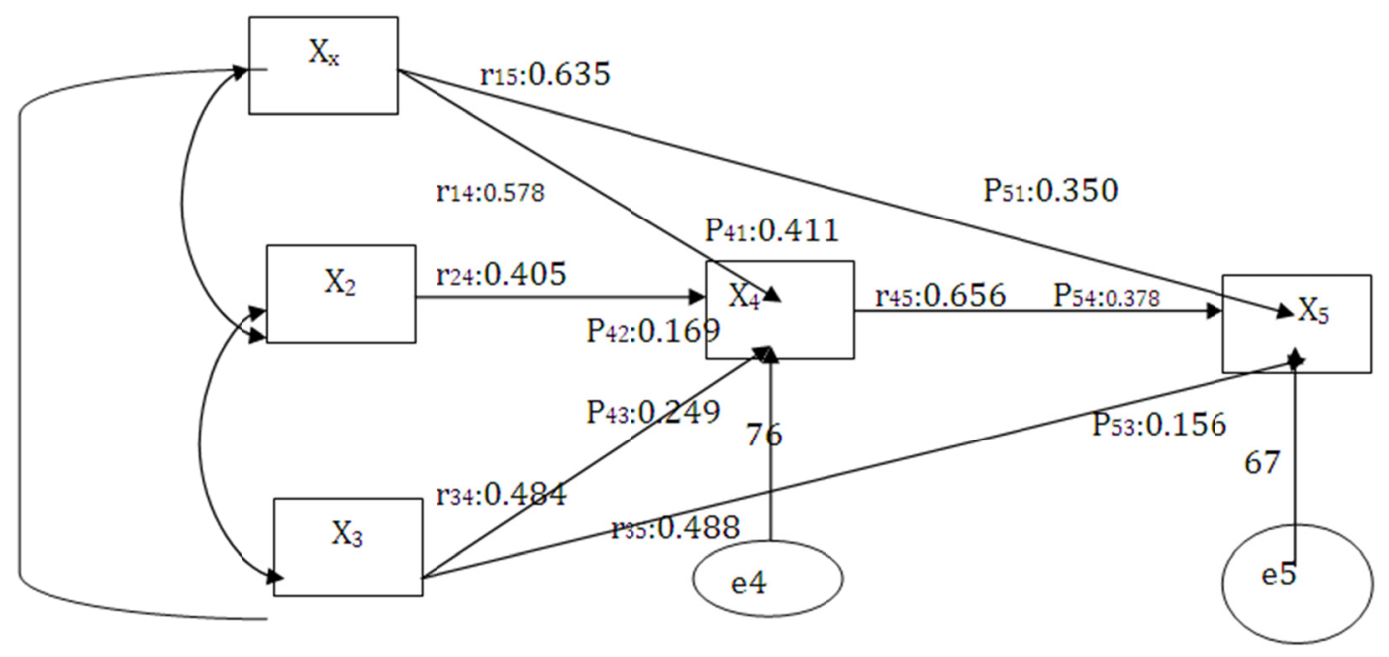

Figure 4. Diagram path analysis theoretic model

After calculation done with formula and entered score value of correlative coefficient, therefore acquired summary on end calculation of path coefficient and correlative coefficient figured on the next table:

Table 7. Summary of correlative coefficient, path coefficient, and significance

\begin{tabular}{llllll}
\hline Correlative & \multirow{2}{*}{$\begin{array}{c}\text { Coefficient } \\
\text { Path Coefficient }\end{array}$} & $\mathrm{T}_{\text {calculation }}$ & \multicolumn{2}{c}{$\mathrm{T}_{\text {table }}$} & \multirow{2}{*}{ Description } \\
\cline { 5 - 5 } & & & $\alpha=0.05$ & $\alpha=0.01$ & \\
\hline $\mathrm{r}_{14}=0.578$ & $\mathrm{P}_{41}=0.411$ & $11.024^{* *}$ & 1.97 & 2.33 & Very Significant \\
$\mathrm{r}_{24}=0.405$ & $\mathrm{P}_{42}=0.169$ & $6.875^{* *}$ & 1.97 & 2.33 & Very Significant\# \\
$\mathrm{r}_{34}=0.484$ & $\mathrm{P}_{43}=0.249$ & $9.761^{* *}$ & 1.97 & 2.33 & Very Significant\# \\
$\mathrm{r}_{15}=0.635$ & $\mathrm{P}_{51}=0.350$ & $16.432^{* *}$ & 1.97 & 2.33 & Very Significant\# \\
$\mathrm{r}_{35}=0.488$ & $\mathrm{P}_{53}=0.156$ & $8.645^{* *}$ & 1.97 & 2.33 & Very Significant\# \\
$\mathrm{r}_{45}=0.656$ & $\mathrm{P}_{54}=0.378$ & $17.771^{* *}$ & 1.97 & 2.33 & Very Significant\# \\
\hline
\end{tabular}

** Very significant.

On summary of end calculation on Table 7 , obviously the value of $t_{\text {calculation }}$ of the six path coefficient is greater than the value of $\mathrm{t}_{\text {table }}$ on $\alpha=0.05$ otherwise the six path coefficient inferred very significant. Then all paths summed up with significant.

\subsection{Discussion and Review}

Some expertise had found several factors which having an effect on performance of individuals or teachers. The factors which impact of individual commonly categorized into internal and external. Another thought suggested individual factor, situational factor. Individual factors included: attitude, personal characteristic, physical type, competency, craving or motivation, education, work experience, sort of training, and supervision, waging system, social environment, work space organizing and work sphere, leadership, and others situational variables. In manner of this study the observed factors are in common with teachers' performance on Public Senior High School around Medan city such as: incentive scheme, teachers personal competency, principal leadership, and work motivation. This matter attested by principal evaluation (evaluator) across 15 items of questions concerning teachers' performance assessment in planning, performance, and learning assessment, whereas 161 people or $68.80 \%$ declared have moderate or adequate job performance, 42 people or $17.42 \%$ stated having high or very good, and the rest of 38 people or $15.77 \%$ affirmed having low or poor job performance. This findings reaffirmed by descriptive statistical analysis result whereas empirical average score of teachers' performance is 
higher in comparison with than ideal score performance. Empirical teachers' performance score as of $52.95 \%$ in the mean time ideal score is 45 . If its compared with empirical average score based classification on data category existing on moderate category or good enough, rather there are many who are under high category or very good. That means teacher's performance of Public Senior High School around Medan city needs to be more elevated. These findings have brought very important about significance toward the officers of Head Educational and Cultural Department of Medan and any institution thereof, which assumed that if the teachers' performance is high or very good, then attainment of educational objective will come easy true.

\section{Conclusion}

Thoroughly scrutinizing of research analysis, therefore some view points to summarize into conclusion:

1) Incentive scheme upon teachers work motivation in Public Senior High School around Medan City, admitted being enough or adequate in category, the incentive scheme has brought an effect in teachers' work motivation with contribution on path coefficient as of 0.411 or $41 \%$. The rest of $59 \%$ caused by other external factors.

2) The subsequent of teachers' personal competency is on the stage of good, it is to qualify to meet the government requirement bylaw No. 14 in the year of $2005 \mathrm{cp} \mathrm{10.} \mathrm{The} \mathrm{contribution} \mathrm{effect} \mathrm{signified} \mathrm{path}$ coefficient of 0.169 or $17 \%$, and the rest of $83 \%$ caused by other external factors.

3) The principal leadership has made an impression toward teachers work motivation on the stage of adequate. The contribution effect pointed to 0.249 or $25 \%$. And the rest of $75 \%$ it depends on other external factors.

4) Incentive scheme on teachers' performance has brought a high effect in category, amid principal evaluation against teachers' work performance hit on the state of good, signified that teachers have positively demonstrated decency in direct contribution of path coefficient of 0.350 or $35 \%$. And indirect contribution as of 0.155 or $16 \%$.

5) The principal leadership by this research analysis categorized reasonable good and has a direct effect on teachers' work performance and significant with a contribution of path coefficient as of $0.156 \%$ or $17 \%$, and indirect effect with path coefficient of 0.094 or $9 \%$.

6) Work motivation brining an effect into teachers' work performance on a high category, work motivation has been positively propelling teachers' work performance directly by contributing path coefficient 0.378 or $38 \%$. And the rest $62 \%$ allegedly influence by others factors.

\section{Recommendation}

\subsection{Theoretical Recommendation}

As clearly defined before about variable research which comprised four exogenous variables they are: Incentive Scheme, Teachers' personal competency, Principal leadership, and work motivation. And endogenous variables are in two variables: Work motivation and Teachers work performance. By theoretical observation that variable work motivation acting as intervening variable. The observation implied that variables exogenous has a direct effect and positively toward endogenous such: 1) Incentive scheme toward work motivation, 2) Teachers personal competence toward work motivation, 3) Principal leadership toward work motivation, 4) Incentive scheme toward teacher's work performance, 5) Principal leadership toward teachers' performance, 6) Work motivation toward teachers' work performance. And the other side of indirect effect among variables included: 1) Incentive scheme has indirect effect on teachers' work performance, 2) Principal leadership has indirect effect on teachers' work performance.

\subsection{Practical Recommendation}

a) Taking care of providing career appraisal, education, workshop training

b) Providing appreciation or rewarding to decent teacher

c) Create and bring up teachers' personal competency including integrity, serve commitment, meet the agreement, self-discipline, role model, good characteristic.

d) Principal practically applying transformational leadership in implementing duties, demonstrating idealism, motivating, imbuing, passionate on personal matters.

e) Providing upgrading system.

\section{References}

Amirullah, \& Hanafi, R. (2002). Pengantar Manajemen. Yogyakarta: Grahallmu. 
Buhler, P. (2004). Alpha Teach Yourself Management Skills, Edisi Pertama. Jakarta: Prenada.

Chamberlin, R., Wragg, T., Haynes, G., \& Wragg, C. (2002). Performance-related pay and the teaching profession: A review of the literature. Research Papers in Education, 17(1).

Colquitt, J., LePine, J., \& Wesson, M. (2009). Organizational Behaviour: Improving Performance And Commitment in The Workplace. New York: McGrawHill.

Daryatno. (2005). Evaluasi Kependidikan. Jakarta: RinekaCipta.

Daum J. H. (2002). Beyond Budgeting: A Model for Performance Management and Controlling in the 21st Century.

Depdiknas. (2004). Pedoman Sertifikasi Kompetensi Pendidik. Jakarta.

Dessler, G. (1998). Manajemen Sumber Daya Manusia Jilid I. Jakarta: Phenhalindo.

Enueme, P. E., \& Egwunyenga, J. E. (2008). Principals' Instructional Leadership Roles and Effect on Teachers' Job Performance: A Case Study of Secondary Schools in Asaba Metropolis, Delta State. Nigeria. J. Soc. Sci., 16(1), 13-17.

Gagne. (1999). Principles of Instructional Design. New York: Rinehart \& Winston.

Gibson, J., Ivancevich, J., \& Donnnelly Jr., J. (2009). Organizational Behaviour, Structure, Process. New York, McGraw-Hill

Griffin. (1997). Management. New Delhi: AITBS Publishers \& Distributor.

Hamalik, O. (2002). Perencanaan Pengajaran Berdasarkan Pendekatan Sistem. Jakarta: BumiAksara

Hasibuan, S. P. M. (2001). Manajemen Sumber Daya Manusia. Jakarta: BumiAksara.

Heneman, L. H. (2007). Implementing Total Rewards Strategies. SHRM Foundation's Effective Practice Guidelines Series.

Hill, T., \& Caroll, S. J. (1997). Organisational Theory and management: A Macro Approach. John willey and Sons Inc, New York.

Killian, S. (2007). The ABC of Effective Leadership: A Practical Overview of evidence Based Leadership Theory. Australian leadership Development Centre

Mangkunegara, A. A. A. (2001). Manajemen Sumber Daya Manusia. Bandung: PT Rosda Karya.

Minner. (1992). Industrial Organizational Psychology. New York: McGraw-Hill.

Moorhead, G., \& Griffin, R. W. (1992). Organizational Behavior (3rd ed.). Houghton Mifflin, Boston

Mulyasa, E. (2004). Manajemen Berbasis Sekolah: Konsep, Strategi, dan Implementasi. Bandung: PT. Remaja Rosdakarya.

Obi, E. (2002). Motivation and Organisational Behaviour. Administration and Management Onitsha: Meks Publishers Ltd.

Robbins, S. P. (2001). Perilaku Organisasi Jilid I. Yogyakarta: Aditya Media Ilmu.

Sardiman. (2004). Belajar dan Pembelajaran. Jakarta: Rajawali Press.

Siswanto, B. (1990). Manajemen Modern (Konsep dan Aplikasi). Bandung: Sinar Baru.

Suryabrata, S. (2004). Psikologi Pendidikan. Jakarta: Grafindo

Syaiful, A. S. (2009). Analisis pengaruh pemberian insentif serta pendidikan dan pelatihan terhadap peningkatan Kinerja guru sekolah menengah atas negeri Di Tebing Tinggi. Tesis: USU.

Winardi. (2002). Motivasi Dan Permotivasian Dalam Manajemen. Jakarta: PT Raja Grafindo Persada.

\section{Copyrights}

Copyright for this article is retained by the author(s), with first publication rights granted to the journal.

This is an open-access article distributed under the terms and conditions of the Creative Commons Attribution license (http://creativecommons.org/licenses/by/3.0/). 